\title{
The use of epoxidized natural rubber for producing rubber seals of LPG tube valves
}

\author{
Hani Handayani", Mohammad Irfan Fathurrohman, Norma Arisanti Kinasih, Asron Ferdian \\ Falaah
}

Indonesian Rubber Research Institute, Salak Street No. 1 Bogor, 16128, Indonesia

Corresponding author. Tel.: +62 8538055 3939; Fax.: +62 2518324047

E-mail: hani.ppkbogor@gmail.com

\author{
Submitted: 13 January $2021 \quad$ Revised: 15 April $2021 \quad$ Accepted: 6 July 2021
}

\begin{abstract}
Rubber seal of Liquified Petroleum Gas (LPG) tube valves should fulfill Indonesian National Standard (SNI 7655:2010), which has high n-pentane resistance properties. This study aimed to design a rubber seal compound based on epoxidized natural rubber which fulfill SNI 7655:2010 requirements. The formulation of compound were designed by using epoxidized natural rubber with varied levels of epoxidation. Epoxidation reaction was occurred in an epoxidation reactor at $70{ }^{\circ} \mathrm{C}$ for 6 hours with $0.75 \mathrm{~mole} / \mathrm{mole}$ isoprene unit of hydrogen peroxide and 0.4 mole/mole isoprene unit of formic acid. Mechanical properties, ageing properties, and swelling performance in $n$-pentane of the modified natural rubber were tested and the result compared to the minimum requirement of SNI 7655:2010. The result showed that the increasing in epoxidation level made natural rubber becomes more polar so it is more resistant to immersion in n-pentane. Epoxidized natural rubber with levels of $40 \%$ and $50 \%$ fulfilled specifications for volume change in accordance with the quality requirements in SNI 7655:2010. The use of natural rubber created good elasticity to all level of epoxidized rubber where these properties are needed for rubber seal of LPG tube valve. However, the formulas of compound were less resistant to aging.
\end{abstract}

Keywords: epoxidized natural rubber, LPG tube valves, oil resistance, rubber seal.

\section{INTRODUCTION}

Natural rubber (NR) is often used in many applications that require high mechanical properties. More than $50 \%$ of NR is used in tires industry especially for buses, heavy duty truck and aircrafts. In addition, NR also used in some nontyre products such as rubber hoses, automotive rubber parts, NR foam mattresses and NR gloves. Natural rubber generally has superior mechanical properties than synthetic rubber. However, natural rubber cannot compete with specialty elastomers, especially with regard to properties, such as resistance to UV, sunlight and ozone, gas permeability and oil resistance (Baker \& Gelling, 1979).

According to SNI 7655:2010, the material for rubber seal LPG tube valve should resistant to $n$-pentane. Acrylonitrile Butadiene Rubber (NBR), a synthetic rubber, is a polar rubber that has resistance to non-polar solvents and oils
(Mostafa et al., 2009; Wang et al., 2014; Choi \& Ha, 2009), however it has low mechanical and dynamical properties. NBR is widely used in many applications which oil resistance is required, such as rubber fuel hoses, rubber gaskets, and roller. Meanwhile, NR has excellent mechanical and dynamical properties (Ismail et al., 2014), however NR is easily attacked by oxygen and ozone due to the presence of abundant amount of double bonds in its main chains (Mei et al., 2012). Moreover, NR is non-polar rubber that easily deformed by oils and hydrocarbon solvents (Tanrattanakul et al., 2003).

The modified products from NR have potential used in manifold rubber products combined with reinforcing fillers, such as carbon black or silica (ten Brinke et al., 2003; Choi et al., 2005) as well as physical blend with other polymers (Okwu \& Okieimen, 2001; Oommen et al., 1996), or chemical modification (Roy et al., 1993), thus 

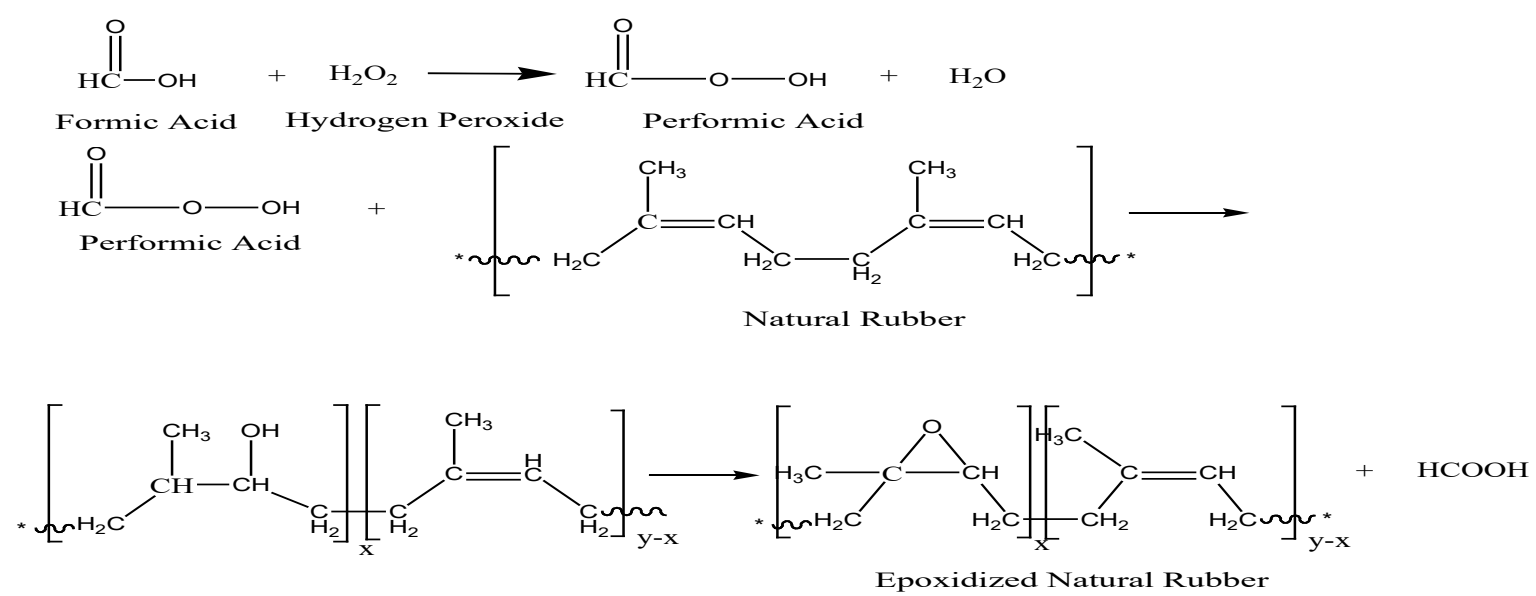

Figure 1. Epoxidation reaction of natural rubber (Baker et al., 1985).

modified NR enable to substitute and compete with synthetic rubbers. One of synthetic rubber which can be substituted with modified natural rubber is NBR. To improve the resistance to oil of natural rubber can be done by chemical and physical modification. The chemical modification of NR through an epoxidation reaction using hydrogen peroxide and formic acid in certain dose produces oil-resistant epoxidized natural rubber (Baker et al., 1985). The presence of epoxide groups in epoxidized natural rubber (ENR) structure showed higher polarity of ENR than NR (Sengloyluan et al., 2012). When natural rubber undergoes an epoxidation reaction, its physical and chemical properties change depends on the degree of epoxidation (Surya et al., 2018). The three most common levels of epoxidation that have been commercially produced, were ENR50, ENR-25, and ENR-10, which referred to 50, 25 , and 10 mole percent of epoxidation level, respectively. ENR-25 and ENR-50 can be used in many applications such as oil resistance and low gas permeability rubber products.

Some rubber products such as engine mounts, tires, rubber bearings, and adhesives, can use ENR as raw material. Moreover, ENR-40 has been used as raw material in rubber components manufacturing for tube valve and regulator of LPG (Handayani et al. 2017). The present study investigated the different levels of epoxidation to produce rubber seal of LPG tube valve

\section{MATERIALS AND METHODS Materials}

The materials used in this study were technical gradefromlocal suppliers. Materials forepoxidation reaction were natural rubber latex, formic acid, hydrogen peroxide, ammonia, anionic surfactant, acetone, and sodium carbonate. Materials for rubber compounding were vulcanization agent (sulphur), activator (stearic acid and zinc oxide), silane Si-69 (bis-triethoxysilylpropyl-tetrasulfide) as coupling agent, color pigment, silica reinforcing filler (Zeosil $175 \mathrm{MP}$ ), curing activator (Rhenofit 1987, Lanxess), rubber crosslinker (Vulcuren [1,6-bis( $N, N$-dibenzylthiocarbamoyldithio)hexane], Lanxess), MMB (methyl-2mercaptobenzimidazole) as antioxidant, DOP (dioctyl phthalate) as plasticizer, DTDM (4,4'dithiodimorpholine), TMTD (tetramethyl thiuram disulfide) and CBS (N-cyclohexylbenzothiazole2-sulphenamide) as accelerator and also Antilux 654 from Rhein Chemie as antiozonant. The equipments used in this study were epoxidation reactor for ENR synthesized and FT-IR Spectroscopy (Thermo Scientific Nicolet iS5) for epoxidation level analysis. Two roll open mill for mixing of rubber with another materials and also Universal Testing Machine (UTM) for testing of rubber physical properties such as tensile strength and elongation at break.

\section{Methods \\ Epoxidation reaction}

Epoxidized natural rubber (ENR) was used as a raw material in rubber seal manufacturing for LPG tube valve. ENR was made through in-situ reaction between natural rubber, formic acid and hydrogen peroxide at $70{ }^{\circ} \mathrm{C}$ with time reaction variation to produce ENR with different 
levels of epoxidation (Kinasih \& Fathurrohman, 2016). Concentrated latex and field latex were used as raw materials to synthesize epoxidized natural rubber in this experiment. Field latex is fresh latex that was obtained from the field after latex being tapped and preserved with ammonia. Concentrated latex was obtained from field latex which was concentrated by centrifugation so that the DRC (Dry Rubber Content) increased from $15-30 \%$ to $60 \%$. Both concentrated and field latex were stabilized using anionic surfactant and, then, reacted with formic acid and hydrogen peroxide with the reaction shown in Figure 1.

The excess acid from the latex epoxidation reaction was neutralized with ammonia, then, it was coagulated with acetone to produce white coagulum. The coagulum formed were washed with water and immersed in sodium carbonate solution, then dried at $80{ }^{\circ} \mathrm{C}$. The synthesized of ENR at different levels was occurred in same condition with different reaction time. The epoxidation latex was then tested for each epoxidation level using FTIR at the Indonesian Rubber Research Institute (IRRI). ENR at different levels was then used as raw material in the manufacturing of rubber seal for LPG tube valve.

\section{Rubber seal compounding}

ENR was mixed with chemicals in the laboratory two-roll open mill based on the compound formulation. The amount of chemical and filler was fixed in the unit of part hundred rubber (phr) and the degree of epoxidation was varied in range of $10 \mathrm{~mole} \%$ to $50 \mathrm{~mole} \%$ as shown in Table 1. The compounds were vulcanized in a laboratory compression machine at $150{ }^{\circ} \mathrm{C}$ to form the $2 \mathrm{~mm}$ rubber vulcanized sheet. Then, its mechanical as well as physical properties were tested according to the reference standard (SNI 7655:2010).

The other chemicals were the same for all formulas

Table 1. The compound formulation with varied levels of ENR.

\begin{tabular}{lccccc}
\hline \multirow{2}{*}{ Materials } & \multicolumn{5}{c}{ Dosage (phr) } \\
\cline { 2 - 6 } & $\mathrm{A}$ & $\mathrm{B}$ & $\mathrm{C}$ & $\mathrm{D}$ & $\mathrm{E}$ \\
\hline ENR-10 & 100 & - & - & - & - \\
ENR-20 & - & 100 & - & - & - \\
ENR-30 & - & - & 100 & - & - \\
ENR-40 & - & - & - & 100 & - \\
ENR-50 & - & - & - & - & 100 \\
\hline
\end{tabular}

which consisted of $50 \mathrm{phr}$ of Silica $175 \mathrm{MP}, 2 \mathrm{phr}$ of Silane Si-69, $2.5 \mathrm{phr}$ of Rhenofit 1987, $1 \mathrm{phr}$ of color pigment, $2 \mathrm{phr}$ of Antilux 654, $1 \mathrm{phr}$ of MMB, $5 \mathrm{phr}$ of DOP, $1 \mathrm{phr}$ of Vulcuren, $1 \mathrm{phr}$ of CBS, 2 phr of TMTD, 1 phr of DTDM, 0.3 phr of sulphur, 5 phr of zinc oxide, and $1 \mathrm{phr}$ of stearic acid.

\section{Physical and mechanical testing}

The physical and mechanical testing of LPG tube valve was conducted according to SNI 7655:2010. The hardness of rubber vulcanized were carried out with Shore A durometer referred to ISO 48-4:2018. In addition, Type 2 dumb-bell test specimens were used for the tensile properties and elongation at break according to SNI ISO 37:2015. Meanwhile, the compression set referred to ISO 815-1:2014 and for swelling volume in $n$-pentane according to ISO $1817: 2015$. The result of mechanical and physical properties were compared to standard quality of rubber seal for LPG tube valve in SNI 7655:2010 (BSN, 2010).

\section{Level of epoxidation analysis}

Levels of epoxidation can be calculated quantitatively by calculating the absorbance in FTIR spectrum. Epoxide rings has characteristics band at wave number $870 \mathrm{~cm}^{-1}$, rings open at wave number $3460 \mathrm{~cm}^{-1}$, the group $-\mathrm{CH}_{3}$ of natural rubber at wave number $1375 \mathrm{~cm}^{-1}$ and unmodified olefins at wave number $835 \mathrm{~cm}^{-1}$. Formula for calculating level of epoxidation (E) was showed as equation (1) according to Chakraborty et al. (2010).

$$
\begin{aligned}
& A_{870 \text { corr }}=A_{870}-\left(0,14 \times A_{835}\right) \\
& A_{3460 \text { corr }}=A_{3460}-\left(0,019 \times A_{1375}\right) \\
& E=\frac{100 \times \text { K1 } \times A_{870 c o r r}}{A_{835}+K_{1} \times A_{870 c o r r}+K_{2} \times A_{3460 c o r r}} x \mathrm{~mol} \%
\end{aligned}
$$

Where $\mathrm{E}$ is epoxy, $\mathrm{K}_{1}$ and $\mathrm{K}_{2}$ is the correction value, wherein the correction is due to the interference of the corresponding bonds and it was estimated to be $14 \%$ and $1.9 \%$, respectively (the value was determined from NMR). The constants $\mathrm{K}_{1}$ and $\mathrm{K}_{2}$ were absolute 0.77 and 0.34 .

\section{RESULTS AND DISCUSSION Epoxidized Natural Rubber}

Two types of latex, concentrated latex with $60 \%$ DRC and field latex with $15 \%$ DRC, were used as raw materials in order to study the effect of latex types to epoxidation reaction. Synthesis of 


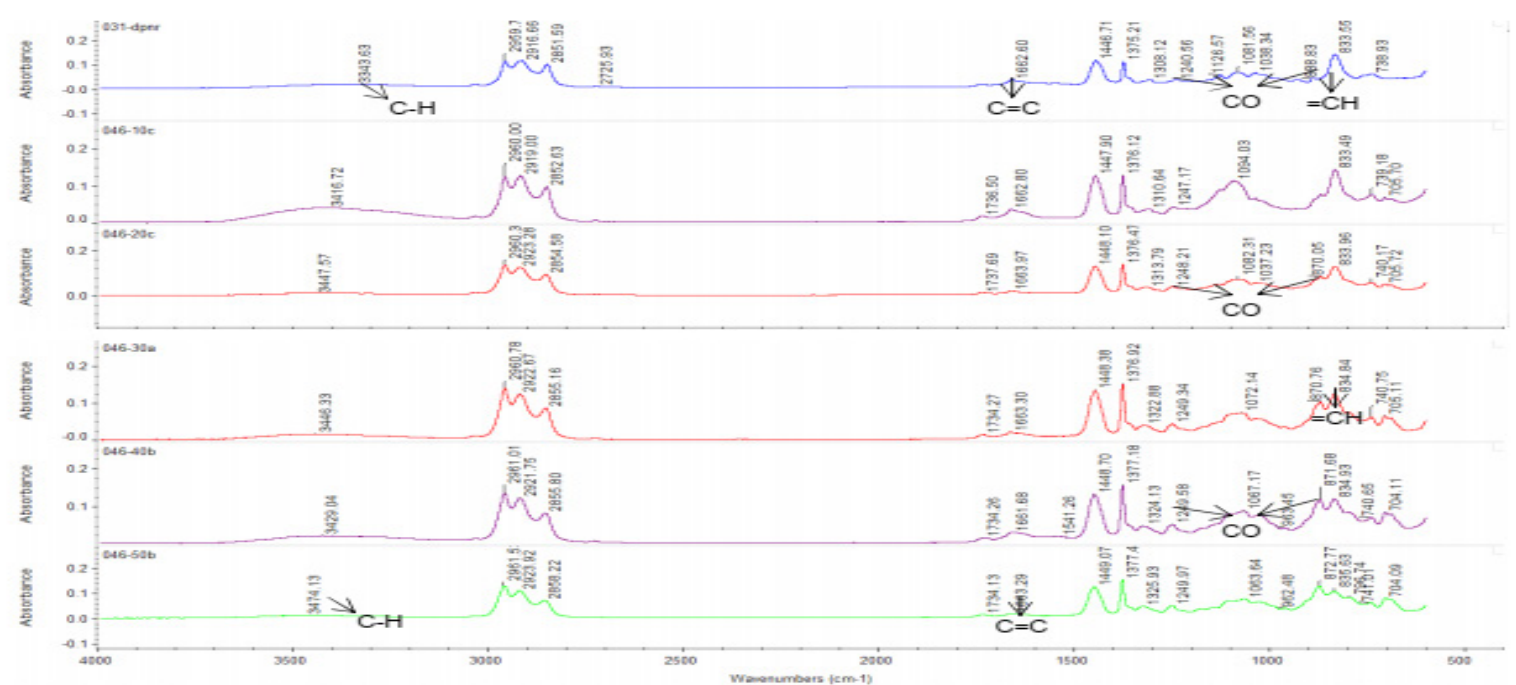

Figure 2. FT-IR spectrum of NR, E-10, E-20, E-30, E-40, and E-50 (from top to bottom).

epoxidized latex was carried out in an epoxidation reactor which was equipped with stirring rod. Epoxidation reaction occurred at $70{ }^{\circ} \mathrm{C}$ for $6 \mathrm{~h}$ with $0.75 \mathrm{~mole} / \mathrm{mole}$ isoprene unit of hydrogen peroxide and $0.4 \mathrm{~mole} / \mathrm{mole}$ isoprene unit of formic acid, the latex was sampling every hour for quantitative analysis of epoxidized level. The reactants, i.e. hydrogen peroxide and formic acid, were added to the latex all at once at the first.

The results of qualitative analysis of E-10, E-20, E-30, E-40, and E-50 are presented in Figure 2. In the figure, it can be seen that when it is compared with FT-IR spectrum of NR, FT-IR spectrum of ENR has absorption characteristics at wave numbers $870 \mathrm{~cm}^{-1}$ and $1251 \mathrm{~cm}^{-1}$ for absorption of bending and stretching of C-O epoxy groups. In the FT-IR spectrum of ENR, it appeared that there was a decrease in the absorption of the $\mathrm{C}=\mathrm{C}$ isoprene group of $\mathrm{NR}$ at wave number of $1600 \mathrm{~cm}^{-1}$ and absorption of stretching C-H alkane groups at wave number $3000 \mathrm{~cm}^{-1}$. The results of qualitative analysis showed that the higher of percent mole epoxy of ENR, the absorption of the $\mathrm{C}=\mathrm{C}$ isoprene group of $\mathrm{NR}$ at wave number of $1600 \mathrm{~cm}^{-1}$ became smaller, and absorption of the $\mathrm{C}-\mathrm{O}$ of the epoxy group at $870 \mathrm{~cm}^{-1}$ and $1251 \mathrm{~cm}^{-1}$ became greater.

Quantitative analysis to determine levels of epoxidation has been done by calculating the absorbance of FTIR spectrum in Figure 2. The

Table 2. Levels of epoxidation with varied of latex type and reaction time.

\begin{tabular}{|c|c|c|c|c|}
\hline Types of Latex & DRC (\%) & Time (hours) & Mole percent of epoxy $(\%)$ & Type of ENR \\
\hline \multirow{7}{*}{ Concentrated latex } & \multirow{7}{*}{60} & 0 & 0.00 & 0 \\
\hline & & 1 & 10.95 & E-10 \\
\hline & & 2 & 21.72 & E-20 \\
\hline & & 3 & 30.07 & E-30 \\
\hline & & 4 & 36.02 & E-35 \\
\hline & & 5 & 41.22 & E-40 \\
\hline & & 6 & 47.08 & E-50 \\
\hline \multirow{7}{*}{ Field latex } & \multirow{7}{*}{15} & 0 & 0.00 & 0 \\
\hline & & 1 & 9.86 & E-10 \\
\hline & & 2 & 18.38 & E-20 \\
\hline & & 3 & 24.45 & E-25 \\
\hline & & 4 & 28.29 & E-30 \\
\hline & & 5 & 32.78 & - \\
\hline & & 6 & 36.01 & E-40 \\
\hline
\end{tabular}


Table 3. Curing characteristics of ENR compounds in variation of epoxidation level.

\begin{tabular}{llrrrrr}
\hline \multicolumn{1}{c}{ Curing Characteristics } & Units & \multicolumn{1}{c}{ A } & \multicolumn{1}{c}{ B } & \multicolumn{1}{c}{ C } & \multicolumn{1}{c}{ D } & \multicolumn{1}{c}{ E } \\
\hline $\mathrm{S}_{\max }-\mathrm{S}_{\min }$ & Minutes & 11.11 & 11.04 & 9.95 & 10.62 & 9.66 \\
$\mathrm{~S}_{\max }$ & Minutes & 11.31 & 11.30 & 10.39 & 11.13 & 9.92 \\
$\mathrm{~S}_{\min }$ & Minutes & 0.20 & 0.26 & 0.44 & 0.51 & 0.26 \\
$\mathrm{~T}_{90}$ & Minutes & 4.31 & 3.29 & 4.28 & 4.02 & 5.05 \\
$\mathrm{TS}_{2}$ & Minutes & 1.15 & 1.18 & 1.31 & 1.40 & 1.55 \\
\hline
\end{tabular}

result showed that epoxidation with concentrated latex resulted higher mole percent of epoxy compared to field latex. The longer time of reaction resulted in higher mole percent of epoxy, not only in concentrated latex but also in field latex. As the reaction time increase, the possibility for molecules to collide with each other increase too, so that it increase the conversions of $\mathrm{C}=\mathrm{C}$ isoprene group of NR to epoxy group.

As in Table 2, epoxidized natural rubber was synthesized from concentrated latex and field latex as raw materials in rubber seal manufacturing for LPG tube valve. Epoxidation reaction from concentrated latex resulted 6 levels of epoxidation i.e. E-10, E- 20, E-30, E-35, E-40 and E-50. In the rubber seal manufacturing for $L P G$ tube valve, we only used 5 type of ENR, i.e., E-10, E-20, E-30, E-40 and E-50. Table 2 shows that type of latex and reaction time affected to the levels of epoxidation. From the data in Table 2, it can be concluded that concentrated latex better to use as raw material for synthesizing epoxidized natural rubber latex than field latex. It was because in concentrated latex, the protein and non-rubber content in latex, which can interfere the epoxidation reaction, has separated and removed by centrifugation so that the epoxidation reaction could run more optimal.

\section{Curing Characteristic}

Table 3 shows the curing characteristic of rubber compound. Compound $\mathrm{A}$ has the highest torque $\left(\mathrm{S}_{\max }\right)$ and different torque $\left(\mathrm{S}_{\max }-\mathrm{S}_{\min }\right)$ among other compounds. While compound E-50 was not suitable due to its cross-linking is the lowest which was indicated by the lowest different torque among other compounds. The different torque is related to the crosslink density of rubber (Surya et al., 2018), the crosslink density decreased with increasing the level of epoxide due to the increasing level of epoxide decreased the amount of double bond in ENR.

\section{Properties of Rubber Seal Compound}

The physical properties of rubber seal compound for LPG tube valve are presented in Table 4. Based on Table 4, the value of hardness, tensile strength, and elongation at break, for all compound, met the requirements in the standard SNI 7655:2010. The presence of natural rubber in the epoxidized natural rubber can improve its elasticity. However, the value of compression set for E-40 compound did not fulfill the requirements in the standard. It could be caused by bad interaction between the filler and E-40 compound.

Table 4. Physical properties of rubber seal compounds with different epoxidation levels.

\begin{tabular}{|c|c|c|c|c|c|c|}
\hline \multirow{2}{*}{ Physical Properties } & \multirow{2}{*}{$\begin{array}{c}\text { Standard } \\
\text { Requirement }\end{array}$} & \multicolumn{5}{|c|}{ Vulcanized } \\
\hline & & $\mathrm{A}$ & B & $\mathrm{C}$ & $\mathrm{D}$ & $\mathrm{E}$ \\
\hline Hardness (Shore A) & $60 \pm 5$ & 55 & 59 & 55 & 57 & 55 \\
\hline Tensile strength (MPa) & Min. 10 & 13.9 & 12.9 & 15.2 & 12.5 & 16.1 \\
\hline Elongation at break (\%) & Min. 300 & 360 & 360 & 420 & 360 & 420 \\
\hline Compression set, temp. $27 \pm 2{ }^{\circ} \mathrm{C}(\%)$ & Max. 10 & 8.97 & 9.76 & 9.62 & 10.36 & 7.79 \\
\hline \multicolumn{7}{|l|}{ Ageing at $70^{\circ} \mathrm{C}, 7 \mathrm{~d}$} \\
\hline - Hardness, change (Shore A) & \pm 10 & 9 & 6 & 7 & 6 & 7 \\
\hline - Tensile strength, change (\%) & \pm 15 & -52.52 & -51.94 & -49.34 & -27.2 & -42.86 \\
\hline - Elongation at break, change (\%) & $+10,-25$ & -50.00 & -58.33 & -50.00 & -41.67 & -50.00 \\
\hline $\begin{array}{l}\text { Swelling volume in } n \text {-pentane at RT, } \\
168 \mathrm{~h}\end{array}$ & Max. +35 & 55.85 & 49.81 & 35.31 & 29.25 & 20.38 \\
\hline
\end{tabular}


Compression set value depends on the interaction between filler and elastomer, the best interaction will result the lowest value of compression set. The greater value of compression set indicates that after being compressed, rubber elasticity decreases (Handayani et al., 2011). Better interaction between filler-ENR will result better compression set.

On the other hand, the tensile strength and elongation at break, after ageing, for all compounds, did not meet the required standards. It can be concluded that all compounds did not resist to aging. To improve the resistance of the compound to ageing, reformulation should be done with the addition of appropriate chemical. Meanwhile, for the swelling properties in n-pentane, compounds with code E-10, E-20, and E-30 did not fulfill the requirements in the standard, while two other compounds fulfilled the standard requirements. It can be concluded that to fulfill the standard requirement of swelling volume, the compound should use ENR contains mole percent of epoxy more than or equal to $40 \%$.

\section{CONCLUSIONS}

From the results of the study, it can be concluded that natural rubber which has been chemically modified by epoxidation reaction can be used as raw material in rubber seal manufacturing for LPG tube valve, with a minimum of $40 \%$ epoxy mole content to fulfill one of the requirements in the referenced standard, SNI 7655:2010, i.e., swelling in n-pentane. The use of natural rubber made good elasticity to all level of epoxidized rubber where this property is needed for rubber seal of LPG tube valve. However, the formulas of the compound are less resistant to aging. To improve the resistance of the compound to ageing, research on re-formulation is still in progress with the addition of appropriate chemical.

\section{ACKNOWLEDGEMENTS}

This work was carried out with the financial support of Ministry of Research and Technology/ National Agency for Research and Innovation the Republic of Indonesia through Sistem Inovasi Nasional (SINAS) grant. Hani Handayani and M. Irfan Fathurrohman as the main contributor for this paper also say thanks to other members as coauthor.

\section{REFERENCES}

Baker, C. S. L., \& Gelling, I. R. (1979). Epoxidized natural rubber. In A. Wheelan, \& K. S. Lee (Eds.), Developments in rubber technology $\left(4^{\text {th }}\right.$ ed., pp. 87-117). Netherlands: Springer.

Baker, C. S. L., Gelling, I. R., \& Newell, R. (1985). Epoxidized natural rubber. Rubber Chemistry and Technology, 58(1), 67-85. https://doi. org/10.5254/1.3536059

BSN (Badan Standardisasi Nasional). (2010). Standard Nasional Indonesia SNI 7655:2010 Karet perapat (rubber seal) pada katup tabung LPG. Jakarta, Indonesia: BSN.

Chakraborty, S., Kar, S., Ameta, R., Dasgupta, S., Mukhopadhyay, R., \& Bandyopadhyay, S. (2010). Quantitative application of FTIR in rubber. Rubber World, 24(1), 33-39.

Choi, S., \& Ha, S. (2009). Influence of the swelling temperature and acrylonitrile content of NBR on the water swelling behaviors of silica-filled NBR vulcanizates. Journal of Industrial and Engineering Chemistry, 15(2), 167-170. https:// doi.org/10.1016/j.jiec.2008.09.016

Choi, S., Hwang, K., \& Kim, B. (2005). Influence of bound polymer on cure characteristics of natural rubber compounds reinforced with different types of carbon blacks. Journal of Applied Polymer Science, 98(5), 2282-2289. https://doi. org/10.1002/app.22287

Handayani, H., Fathurrohman, M. I., \& Kuncoro, I. (2011). Karakteristik sifat fisik dan ketahanan terhadap minyak dari karet alam epoksi. Jurnal Penelitian Karet, 29(1), 49-62. https://doi. org/10.22302/ppk.jpk.v29i1.111

Handayani, H., Fathurrohman, M. I., Kinasih, N. A., \& Falaah, A. F. (2017). Karet alam epoksi sebagai bahan baku pembuatan komponen karet pada katup tabung dan regulator LPG. Jurnal Penelitian Karet, 35(2), 199-210. https://doi.org/10.22302/ ppk.jpk.v35i2.416

Ismail, H., Majid, R. A., \& Taib, R. M. (2014). Effects of dynamic vulcanization on tensile, morphological, and swelling properties of poly(vinyl chloride) (PVC)/epoxidized natural rubber (ENR)/(Kenaf core powder) composites. Journal of Vinyl \& Additive Technology, 22(3), 206-212. https://doi. org/10.1002/vnl.21401

Kinasih, N. A., \& Fathurrohman, M. I. (2016). Pengaruh kondisi reaksi terhadap karakteristik ketahanan karet alam epoksi dalam n-pentana. Jurnal Sains Materi Indonesia, 17(3), 102-109. https://doi. org/10.17146/jsmi.2016.17.3.4190

Mei, C., Yong-Zhou, W., Guang, L., \& Xiao-Ping, W. (2012). Effects of different drying methods on the microstructure and thermal oxidative aging resistance of natural rubber. Journal of Applied Polymer Science, 126(6), 1808-1813. https://doi. org/10.1002/app.34300

Mostafa, A., Abouel-Kasim, A., Bayoumi, M. R., \& 
El-Sebaie, M. G. (2009). Effect of carbon black loading on the swelling and compression set behavior of SBR and NBR rubber compounds. Materials \& Design, 30(5), 1561-1568. https:// doi.org/10.1016/j.matdes.2008.07.043

Okwu, U. N., \& Okieimen, F. E. (2001). Preparation and properties of thioglycollic acid modified epoxidised natural rubber and its blends with natural rubber. European Polymer Journal, 37(11), 2253-2258. https://doi.org/10.1016/ $\underline{\mathrm{S} 0014-3057(01) 00112-4}$

Oommen, Z., Nair, M. R. G., \& Thomas, S. (1996). Compatibilizing effect of natural rubber-gpoly(methyl methacrylate) in heterogeneous natural rubber/poly(methyl methacrylate) blends. Polymer Engineering \& Science, 36(1), 151-160. https://doi.org/10.1002/pen.10396

Roy, S., Bhattacharjee, S., \& Gupta, B. R. (1993). Hydrogenation of epoxidized natural rubber. Journal of Applied Polymer Science, 49(3), 375380. https://doi.org/10.1002/app.1993.070490301

Sengloyluan, K., Sahakaro, K., Dierkes, W. K., \& Noordermeer, J. W. M. (2012). Use of epoxidized natural rubber as compatibilizer in silica-filled natural rubber compounds. Paper presented at $28^{\text {th }}$ International Conference of the Polymer Processing Society, 1-4.

Surya, I., Maulina, S., \& Ismail, H. (2018). Effects of alkanolamide and epoxidation in natural rubber and epoxidized natural rubbers compounds. IOP Conference Series: Materials Science and Engineering, 299, 012061. https://doi. org/10.1088/1757-899X/299/1/012061

Surya, I., Hayeemasae, N., \& Ginting, M. (2018). Cure characteristics, crosslink density and degree of filler dispersion of kaolin-filled natural rubber compounds in the presence of alkanolamide. IOP Conference Series: Materials Science and Engineering, 343, 012009. https://doi. org/10.1088/1757-899X/343/1/012009

Tanrattanakul, V., Wattanathai, B., Tiangjunya, A., \& Muhamud, P. (2003). In situ epoxidized natural rubber: Improved oil resistance of natural rubber. Journal of Applied Polymer Science, 90(1), 261269. https://doi.org/10.1002/app.12706

ten Brinke, J. W., Debnath, S. C., Reuvekamp, L. A. E. M., \& Noordermeer, J. W. M. (2003). Mechanistic aspects of the role of coupling agents in silica-rubber composites. Composites Science and Technology, 63(8), 1165-1174. https://doi. org/10.1016/S0266-3538(03)00077-0

Wang, H. M., Lv, X. R., \& Wang, S. J. (2014). The swelling properties of nitrile rubber with different acrylonitrile contents in cyclohexane medium research. Advanced Materials Research, 936, 1942-1947. $\quad \underline{\text { https://doi.org/10.4028/www. }}$ scientific.net/amr.936.1942 
